\title{
SYMPOSIUM ON GLOBAL LABS OF INTERNATIONAL COMMERCIAL DISPUTE RESOLUTION
}

\author{
THE RESOLUTION OF INTERNATIONAL COMMERCIAL DISPUTES - WHAT \\ ROLE (IF ANY) FOR CONTINENTAL EUROPE?
}

\author{
Giesela Rübi
}

The past sixteen years have witnessed the proliferation of international commercial courts ${ }^{1}$ around the world. ${ }^{2}$ However, up until recently, this was largely an Asian and a Middle Eastern phenomenon. Only during the past decade have Continental European countries, notably Germany, France and the Netherlands, joined the bandwagon and started to create new judicial bodies for international commercial cases. Driven by the desire to attract high-volume commercial litigation, these bodies try to offer international businesses a better dispute settlement framework. But what are their chances of success? Will more international litigants decide to settle their disputes in these countries? In this essay, I argue that, despite its recently displayed activism, Continental Europe lags behind on international commercial courts. In fact, although the various European initiatives are laudable, most cannot compete with the traditional market leaders, especially the London Commercial Court, or with new rivals in Asia and the Middle East. If Continental Europe wants a role in the international litigation market, it must embrace more radical change. And this change will most likely have to happen on the European—not the national—level.

\section{Battle of the Brochures and First Initiatives}

The catalyst for the recent Continental European efforts to improve the international commercial dispute settlement framework was the United Kingdom's decision to leave the European Union. However, competition for international litigation pre-dates the 2016 Brexit referendum. The origins can be found in 2007 when the Law Society of England and Wales published a brochure entitled "England and Wales: The jurisdiction of choice."3 It praised English law as the law for international contracts and English courts as the place for the settlement of international commercial disputes. And it bluntly presented the English legal system as superior to legal systems in civil law countries.

Not surprisingly, the brochure was not met with enthusiasm on the European Continent. German lawyers, therefore, decided to fight back by publishing their own brochure. Entitled "Law - made in Germany,"4 it

* Professor of Law, Humboldt-University of Berlin, Berlin, Germany

1 "International commercial courts" here includes specialized chambers for international commercial matters.

2 See, e.g., Pamela Bookman, The Adjudication Business, 45 Yale J. Int'L L. 227 (2020); Matthew Erie, The New Legal Hubs: The Emergent Landscape of International Commercial Dispute Resolution, 60 VIRGINIA J. INT'L L. 226 (2020).

${ }^{3}$ The Law Society of England and Wales, England and Wales: The jurisdiction of choice (2008).

${ }^{4}$ See www.lawmadeingermany.de; Stephan Vogenauer, Regulatory Competition Through Choice of Contract Law and Choice of Forum in Europe: Theory and Evidence, 21 Eur. Rev. Priv. L. 13, 31 (2013).

(C) Giesela Rühl 2021. This is an Open Access article, distributed under the terms of the Creative Commons Attribution licence 11 (http://creativecommons.org/licenses/by/4.0/), which permits unrestricted re-use, distribution, and reproduction in any medium, provided the original work is properly cited. 
advertised - no less bluntly than its English counterpart - the alleged advantages of German law and German courts vis-à-vis English law and English courts. ${ }^{5}$ In addition, German lawyers also reached out to their French colleagues to promote the use of continental law and continental courts more broadly. The result: yet another brochure. $^{6}$

One may, of course, be amused at these superficial attempts to bring more international commercial disputes to Continental Europe. But the "battle of the brochures" provided the parting shot for a number of national initiatives aimed at increasing the attractiveness of Continental European national courts for international litigants. In Germany and France, for example, specialized English-language chambers for international matters were created at the District Courts of Aachen, Cologne and Bonn and at the Paris Commercial Court in 2010. ${ }^{8}$ And in the same year, the Upper House of the German Parliament introduced a draft bill to establish international commercial chambers at the District Court and Court of Appeals levels offering full English-language legal proceedings.

In the end, however, these initial efforts did not yield much success: demand for the newly established court chambers turned out to be very low and the German draft bill was never debated in the Lower House of the German Parliament. A second attempt to turn the bill into law suffered the same fate four years later. ${ }^{10}$

\section{Brexit and Recent Initiatives}

Following these early attempts, competition for international commercial disputes stalled for some time. Only one country - the Netherlands - persisted in this endeavor and started to build a new court specifically designed to deal with international cases. In Germany and France, in contrast, the battle for international litigants only regained momentum after the Brexit referendum in 2016. In the hope of being able to get a bigger piece of the dispute resolution pie, both Germany and France expeditiously announced the establishment of new judicial bodies to lure litigants from London to the Continent.

\section{International Commercial Chambers in Germany}

In Germany, a group of scholars, judges, and politicians from the Federal State of Hesse first realized that Brexit-beyond the many unfortunate consequences-might also offer opportunities. They devised the "Frankfurt Justice Initiative"11 and successfully proposed establishing a special chamber for international commercial matters at the District Court of Frankfurt. The new chamber officially opened in January 2018 and hears international commercial cases in English. In addition, the newly created chamber promises to use the leeway offered by the German law of civil procedure to make court proceedings more efficient.

The Frankfurt example quickly inspired other German States to follow suit. In May 2018, Hamburg announced the creation of two English-language chambers at its District Court, ${ }^{12}$ one for civil and one for commercial

\footnotetext{
${ }^{5}$ Bundesnotarkammer et al., LaW - Made in Germany. Global. Effective. Cost-Efficient (1st ed. 2008, 2d ed. 2012, 3d. ed. 2014).

${ }^{6}$ Association des Juristes Français et Allemands et al., Continental Law. Global. Predictable. Flexible. Cost-Effective (2011).

${ }^{7}$ Vogenauer, supra note 4, at 30.

8 See Christoph Kern, English as a Court Language in Continental Courts, 5 Erasmus L. Rev. 192, 195 ff. (2012).

${ }^{9}$ Gesetzesantrag vom 27. Januar 2010, BR-Drucksache 42/10.

${ }^{10}$ Gesetzesantrag vom 6. März 2014, BR-Drucksache 93/14.

${ }^{11}$ Burkhard Hess \& Timon Boerner, Chambers for International Commercial Disputes in Germany: The State of Affairs, 12 ERASMUs L. REv. 33

12 See State of Hamburg, Landgericht Hamburg: Englischsprachige Kammern für Zivil- und Handelssachen ab Mai 2018 (Apr. 30 ,
} (2019). 2018). 
matters. ${ }^{13}$ And in November 2020, the State of Baden-Wuerttemberg opened two Commercial Courts ${ }^{14}$ at the District Courts of Mannheim and Stuttgart. ${ }^{15}$ Both Commercial Courts hear high-value international cases under the guidance of experienced judges, well-versed in both English and international matters. According to information provided on the official website, the Commercial Courts will conduct proceedings "quickly, dynamically and efficiently" including through measures such as pre-hearing meetings, as conducted in English courts and international commercial arbitration. The Courts of Appeals of Stuttgart and Karlsruhe will hear appeals in the same spirit.

Finally, the prospect of Brexit also led to the reintroduction of the above-mentioned draft bill to establish international commercial chambers at the District Court and Court of Appeals levels. ${ }^{16}$ Of course, one may wonder whether-in light of the many international chambers that were recently established - the law is still needed. However, the law is necessary to make sure that courts, including the already existing international chambers, may actually conduct full English-language legal proceedings: under the current German Court Constitution Act and the Code of Civil Procedure the use of the English language is limited to the oral hearing and the submission of documents whereas court decisions and the minutes of the proceedings still must be delivered in German. ${ }^{17}$ Since this might explain why earlier attempts to allow parties to speak English in courts yielded little to no success, one can only hope that the draft bill will eventually be adopted. Thus far, however, it has stalled. In fact, it has not been discussed in the Lower House of the German Parliament since its introduction in February 2018. And chances that a meaningful debate will take place in the near future are becoming slimmer every day, especially since the global health pandemic is currently consuming most of the political and legislative attention.

\section{International Commercial Chambers in France}

In addition to Germany, France was also quick to recognize the opportunities that might arise from Brexit in the field of international commercial dispute resolution. It reacted, similarly to Germany, by creating an international chamber at the Court of Appeals in Paris. ${ }^{18}$ Operating since March 2018, the new chamber hears transnational commercial disputes and appeals from the international chamber at the Paris Commercial Court. ${ }^{19}$ Like the newly created German international chambers, the Paris chamber conducts proceedings in English. ${ }^{20}$ However, the use of the English language is limited, as in Germany. In particular, procedural acts including judgments have to be drafted in French. ${ }^{21}$

Beyond the use of the English language, the new Paris chamber resembles the various German initiatives in yet another respect: it promises to conduct proceedings in a way that corresponds to international standards in dispute

\footnotetext{
${ }^{13}$ According to $\iint 75,105,108$ of the German Court Constitution Act, civil and commercial chambers differ in their composition: while civil chambers are staffed with three professional (career) judges, commercial chambers are staffed with one professional judge and two lay judges drawn from the local business community and appointed for five years.

${ }^{14}$ Note that the two new "Commercial Courts" are just two more new court chambers for civil and commercial matters. For the composition of the two chambers see $\int \mathbb{S} 75,105,108$ of the German Court Constitution Act.

15 See commercial-court.de/en/.

${ }^{16}$ Gesetzesantrag vom 20. Februar 2018, BR-Drucksache 53/18

${ }_{17}$ Cf. SS 184, 185 Court Constitution Act.

18 See, e.g., Alexandre Biard, International Commercial Courts in France: Innovation Without Revolution?, 12 Erasmus L. REv. 24 (2019).

19 Art. 1.1. and Art. 1.2. of the Protocol on Procedural Rules Applicable to the International Chamber of the Court of Appeals of Paris of January 26, 2018.

${ }^{20}$ See id. Art. 2.4.

${ }^{21}$ Id. Arts. 2.1. and 7.
} 
resolution. And as in Germany, the procedural innovations are implemented bottom-up without any change to the overall legal framework. More specifically, they do not follow from amendments to the French Code of Civil Procedure, but from a Protocol signed by the Bar, the Court of Appeal, and the Ministry of Justice, which does not have the force of law. How this arrangement will play out in practice remains to be seen. Should the Paris international chamber indeed follow the Protocol, it will conduct the proceedings in a manner that borrows heavily from both international commercial arbitration and English law.

\section{The Netherlands Commercial Court}

The aftermath of the Brexit referendum also saw the establishment of the Netherlands Commercial Court in January 2019. However, in contrast to the German and French international chambers, the Netherlands Commercial Court was already in the making when the United Kingdom decided to leave the European Union in 2016. In fact, the Dutch Council for the Judiciary had already realized in 2014 that Dutch courts were losing high-profile international commercial cases and decided to stop the downward trend. ${ }^{22}$ Set up as a special chamber in the Amsterdam District Court, the Netherlands Commercial Court hears international commercial cases and conducts its entire proceedings in English and in accordance with procedural rules specifically designed for complex international cases. Appeals will be heard in English by the Netherlands Commercial Court of Appeal, a newly created chamber at the Amsterdam Court of Appeals.

In light of the above, it seems fair to say that the Netherlands Commercial Court, together with the Netherlands Court of Appeals, goes beyond what the newly created German and French international commercial chambers are offering. This also holds true for two additional reasons. First, the Netherlands Commercial Court and the Netherlands Commercial Court of Appeal hold their hearings in the Palace of Justice in Amsterdam, a modern court building with modern facilities, including teleconferencing, videoconferencing and sound recording technologies. Second, both courts will soon be accessible via an online platform that will, if implemented, allow full electronic communication and exchange of documents between the court, counsel, and parties. In both respectsfacilities and online access — there remains much to be done in both Germany and France.

\section{Prospects of Success}

There is no denying the fact that the Continental European market for the resolution of international commercial disputes is currently undergoing change. And although the situation is still in flux, there can be little doubt that the various national initiatives have made Continental Europe a better place for the settlement of international commercial disputes. In particular, they have given English— the lingua franca of international trade—a more prominent role in court proceedings. And they have induced a movement towards more procedural flexibility inspired by international best practice.

However, there should also be little doubt that the various national initiatives will not be game changers. In fact, it is hard to believe that they will dramatically increase the attractiveness of Continental European countries for international litigants. ${ }^{23}$ Doubts are in order because most of the national initiatives do not go very far. Especially when compared to other international commercial courts, it is evident that Continental Europe is taking fairly small steps forward. This holds particularly true for Germany and France. Here the newly established international chambers-in contrast to, for example, the international commercial courts in Abu Dhabi, Dubai, Kazakhstan,

\footnotetext{
22 See, e.g., Jeroen A. van der Weide, The Netherlands Commercial Court (NCC): Its Challenges and Perspectives, in CommerCIAL Dispute Resolution, in Europe, China and World 81, 83 (Lei Chen \& André Janssen eds., 2020).

23 See, e.g., Giesela Rühl, Auf dem Weg zu einem europäischen Handelsgericht?, JuRIstenZeitung 1073, 1078 (2018).
} 
Qatar and Singapore-are not allowed to offer full English-language proceedings. In addition, they can adjust the way they conduct the proceedings only within the limits of their national rules of civil procedure. And although these rules offer some leeway to account for the expectations of international litigants, there is no changing the fact that the international chambers are still offering essentially German and French court proceedings. Finally, and again in stark contrast to the international commercial courts in Abu Dhabi, Dubai, Kazakhstan and Qatar, the European courts are chambers of already existing national courts. Judges are, therefore, not drawn from a variety of different jurisdictions but from Germany and France only. As a consequence, the international commercial chambers are mainly international in the sense that they deal with international cases.

Prospects look better when turning to the Netherlands. Here, both the Netherlands Commercial Court and the Netherlands Commercial Court of Appeal present themselves as far better options to settle international commercial disputes. Both courts conduct proceedings entirely in English and follow rules of procedure that were drafted specifically with international cases in mind. Nonetheless, it is far from clear that the newly founded Dutch courts will thrive. Both the Netherlands Commercial Court and the Netherlands Commercial Court of Appeal remain embedded in national structures: they are special chambers of existing courts and they are staffed with Dutch judges only. Against this background, it remains to be seen whether the latest addition to the Continental European dispute resolution landscape will be able to attract international litigants and to compete with traditional market leaders such as the London Commercial Court. This also holds true because the London Commercial Court owes its success to the (perceived) quality of English substantive law. ${ }^{24}$

\section{Outlook: A European Commercial Court?}

In light of the above analysis, it seems that more substantial change will be necessary to turn Continental Europe into a serious competitor on the global market for international litigation. However, I am pessimistic that this change can happen at the national level. To be sure, there is no lack of innovative and promising proposals. But, given the failure of much less far-reaching reform projects, there is little hope that these suggestions will be implemented anytime soon. The inertial forces of national traditions and resistance from within national judiciaries simply seem too strong.

In addition, it also seems inefficient to invest in many national projects that will, in the end, only unnecessarily compete with each other. I have, therefore, suggested elsewhere that Continental European countries should join forces and invest in the creation of a common European Commercial Court. ${ }^{25}$ Such a court would send a clear signal to the world that Europe is a good place to conduct international commercial litigation. Unlike the national courts, it would be a truly international court. It could be built from scratch and without the limits of structures that have developed nationally over centuries and without international cases in mind. In particular, it could be staffed with judges from different states, ideally representing different legal traditions and professions. These judges would ensure that the Court has the necessary expertise and experience to settle international disputes. They would also credibly signal that the Court is unlikely to favor one of the parties for reasons of nationality.

\footnotetext{
${ }^{24}$ Eddy Bauw, Commercial Litigation in Europe in Transformation: The Case of the Netherlands Commercial Court, 12 ERASmus L. REv. 15, at 21 (2019); Harriët Schelhaas, The Brand New Netherlands Commercial Court: A Positive Development?, in International Business CourTs 45, 60-61 (Xandra Kramer \& John Sorabji eds., 2019).

${ }^{25}$ Giesela Rühl, Building Competence in Commercial Law in the Member States 58-63 (Study for the JURI Committee, PE 604.980, September 2018); Rühl, supra note 23, at 1079-81.
} 
Of course, it remains to be seen whether the European legislature will eventually take up the proposal. While the European Parliament has expressed its support, ${ }^{26}$ hopes should not be too high. For one, the European Commission, despite signaling interest in exploring these options, has reacted with caution so far. ${ }^{27}$ And for another, one cannot expect support from those Member States_France, Germany and the Netherlands-that have already invested in building their own international commercial courts. Nevertheless, one thing seems certain: Continental Europe is on the move and the dispute resolution landscape will continue to change. The coming years will tell whether individual countries or Europe as such will be competitive in the market for international commercial litigation.

26 See, e.g., European Parliament Resolution of 13 December 2018 with Recommendations to the Commission on Expedited Settlement of Commercial Disputes (2018/2079(INL)), Annex, III. 3.

27 See, e.g., European Commission, Follow-up to the European Parliament Non-Legislative Resolution with Recommendations to the Commission on Expedited Settlement of Commercial Disputes (SP(2019) 129) 3. 